\title{
The role of plant-parasitic nematodes on productivity reduction of banana and tomato in East Kalimantan, Indonesia
}

\author{
SUYADI", ROSFIANSYAH ${ }^{\vee \vee}$ \\ ${ }^{1}$ Department of Agroecotechnology, Faculty of Agriculture, Universitas Mulawarman. Jl. Pasir Belengkong Samarinda 75119, East Kalimantan, \\ Indonesia. Tel.: +62-541-749343, ^email: suyadi@faperta.unmul.ac.id, rw rosfiansyah@yahoo.com
}

Manuscript received: 27 September 2016. Revision accepted: 27 June 2017.

\begin{abstract}
Suyadi, Rosfiansyah. 2017. The role of plant-parasitic nematodes on productivity reduction of banana and tomato in East Kalimantan, Indonesia. Asian J Agric 1: 40-45. Plant-parasitic nematodes are one of the most limiting factors of agricultural ecosystem productivity in East Kalimantan. But their occurrence in agricultural fields as a crop's pest is generally undistinguished, due to their microscopic size and their existence being wrapped in the roots or soil particles. However, plant-parasitic nematodes might cause yield loss of up to $75 \%$, without showing any disease symptoms on crop morphologically. Both perennial crops and annual crops under intensive cultivation usually experience high yield loss due to plant-parasitic nematodes if crop protection management was not implemented properly. This research aimed to determine the role of plant-parasitic nematodes in reducing crop productivity in East Kalimantan, in relation to agricultural practices implemented by farmers. Descriptive research and comparative analyses were implemented to determine the role of plant-parasitic nematodes on yield reduction of banana and tomato as the indicator of productivity. Based on the field observation related to pest management in East Kalimantan, it was determined that plant-parasitic nematode existence was neglected by farmers and no significant effort was implemented to control plant-parasitic nematodes population. Therefore, low productivity of agricultural ecosystem in East Kalimantan was reported by Statistical Office. This was not only caused by soil fertility problems, but in some crops, it was also the impact of population outbreak of plant-parasitic nematodes. The first ranking three genera of plant parasite nematodes observed in East Kalimantan were Meloidogyne, Radhopholus, and Rotylenchulus, respectively. Meloidogyne and Rotylenchulus were major pests on vegetables and caused a yield loss of $>50 \%$ on tomato. While genus of Radhopholus was the major pest on banana and caused a yield loss of $>75 \%$ on banana.
\end{abstract}

Keywords: Banana, East Kalimantan, nematode, productivity reduction, tomato, yield loss

\section{INTRODUCTION}

Plant-parasitic nematodes (PPN) were important pests in East Kalimantan Province of Indonesia, compared to other pests, PPN caused highest yield loss on some crops. However, their existence in the field is still neglected by farmers because they could not distinguish the existence of PPN directly in the field, with plants being symptomless during the early stage of infection. Additionally, no serious efforts were implemented to control their populations. Worldwide crops yield loss due to PPN has been estimated at \$US 80 billion per year, and this is likely to be a significant underestimate of the true figure, as many growers, particularly in developing nations, are unaware on PPN existence (Jones et al. 2013).

Yield loss due to PPN varies as it can be affected by environmental factors, cropping systems and pest management practices. Reported by Jones et al. (2013) that Meloidogyne graminicola caused yield losses of up to $87 \%$ on rice. Whereas cyst nematodes (Heterodera and Globodera spp.) under specific environmental conditions caused yield losses of up to $90 \%$. Pratylenchus spp. caused yield losses of up to $30 \%$ on wheat in Australia. Finally, reniform nematode (Rotylenchulus reniformis) caused yield losses of $40 \%-60 \%$. Furthermore, reported by Singh and Kumar (2015) that yield loss on vegetable crops in Western Uttar Pradesh varied from $4 \%$ on bitter gourd (Momordica charantia) to up to $43 \%$ on eggplant (Solanum melongena), and Meloidogyne incognita was determined as the most important PPN in Uttar Pradesh, this nematode genus involved in the first rank of causal yield losses, on eggplant $(43 \%)$, tomato $(40 \%)$, and okra (38\%).

Banana yield loss due to burrowing nematodes can reach more than 50\% (Bartholomew et al. 2014) or range from 30 to $60 \%$ (Brooks 2014). Moreover, reported by Hölscher et al. (2014) that burrowing nematodes might cause yield loss of up to $75 \%$ on banana. Higher banana yield loss commonly occurred in developing countries, because control efforts for this parasite is still limited (Chitamba et al. 2013; Kamira et al. 2013; Srinivasan et al. 2011), and there were some important genera of PPN attacking banana altogether with burrowing nematodes, i.e., Meloidogyne (root-knot), Pratylenchus (lesion), Helicotylenchus (spiral), Rotylenchulus (reniform) (Brooks 2014; Kamira et al. 2013; Srinivasan et al. 2011). Whereas, banana yield loss was relatively reduced under commercial banana cultivation, where integrated pest management (IPM) technology was implemented (Ricède et al. 2010).

Tomato yield loss due to PPN ranged from $25 \%$ up to $100 \%$ and the main nematode genus attacking tomato was Meloidogyne (Seid et al. 2015). As well as in the banana case, yield loss due to PPN on tomato mostly occurred in developing countries, because of poor control efforts 
implemented to the parasite. Whereas PPN in developed countries was relatively well managed and more control technique alternatives were available. The availability of resistant cultivars apparently was the most prospective control technique for PPN on tomatoes (Rani et al. 2009; Gharabadiyan et al. 2013). However, the most practical control measure applicable in East Kalimantan was soil amendment of dung manure (Aalders et al. 2009) which prevented tomato yield loss direct and indirectly.

Research activities related to PPN and their management in East Kalimantan are still limited. The most intensive research on PPN which was conducted in East Kalimantan, was focused on bananas and tomatoes. Because the symptoms of PPN attacking both crops are relatively easy to observe, i.e., root galls on tomato, root rot or blackhead on banana which caused toppling disease. The purpose of this research was to determine the role of PPN on productivity reduction of banana and tomato, as the indicator of crop yield loss due to PPN in East Kalimantan. Furthermore, this research aims to expand farmers understanding of the existence of PPN as an important pest in the province, with the hopes that farmers could control them properly.

\section{MATERIALS AND METHODS}

\section{Study area}

Field observations and surveys to determine the existence of PPN on tomato and banana were conducted at production centers of banana and tomato in East Kalimantan Province, Indonesia. Banana production areas were distributed in almost all the districts in East Kalimantan, whereas tomato production areas were only found in Balikpapan municipal, Kutai Kartanegara and Penajam Paser Utara districts. Production centers of bananas are commonly located along province main road and along rivers in the province (Figure 1).

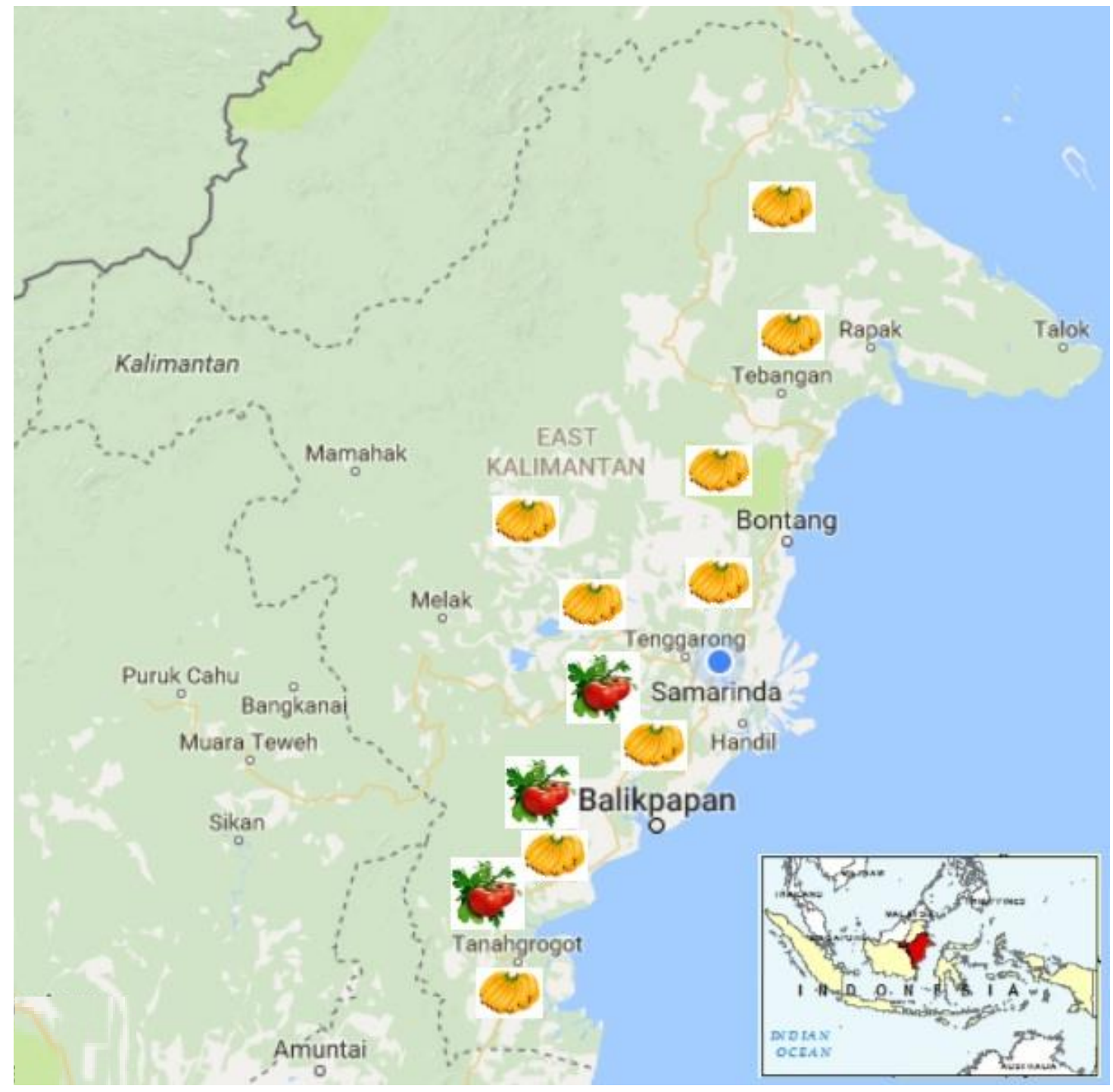

Figure 1. The production center sites of banana and tomato in East Kalimantan Province, Indonesia. The banana and tomato centers are indicated by the banana and tomato symbols 


\section{Procedures}

This research was a combination of field and desk research. Field research was focused on the determination of the existence of PPN attacking the crops, and their impact on crop productivity reduction. The primary data was gathered from field research, i.e.: PPN genera attacking tomato and banana, population densities of each PPN genus, and the actual yield of banana and tomato under traditional cultivation system implemented by farmers. Secondary data about productivity, production, and harvested or cultivated area of banana and tomato, was gathered from the formal data reported by the Statistic Center Bureau of East Kalimantan Province.

\section{Field research}

Field surveys and observations were carried out to gather primary data, to determine the existence of PPN attacking tomato and banana at the sites of production center, as well as actual or attainable yield of both crops at each farmer's field. Crops yield and productivity were directly observed and measured or counted in the field. While PPN genera and their population densities were gathered from soil and roots samples. Then, nematodes extractions were conducted at the laboratory, soil samples were processed by Baermann Funnel Method and root samples were processed through the Direct Maceration Method.

\section{Desk research}

The main purpose of desk research was to gather a time series of secondary data, which was available and reported formally by the Statistic Center Bureau of East Kalimantan Province. Secondary data required included: crop production (yield), productivity, and harvested area of banana and tomato in East Kalimantan. The secondary data used in this research covered at least a five year period, to elaborate the dynamic of banana and tomato production in the province.

\section{Data analysis}

Comparative data analysis was implemented in this research to describe the role of PPN on banana and tomato productivity reduction. Data analysis was conducted based on the secondary data and justified by the primary field data, comparatively. Therefore, the description of time series secondary data of banana and tomato production in the province was elaborated to explain the relationship occurrences between the existence of PPN and productivity reduction on bananas and tomato.

\section{RESULTS AND DISCUSSION}

\section{The productivity of tomato}

Tomato farmers in East Kalimantan always cultivated their crops under intensive management, especially in terms of fertilizer application and aboveground pest control, but plant-parasitic nematodes control efforts were still neglected. Consequently, they harvested only limited yields of tomato, and the average annual productivity was still very far from the potential and attainable yield of the crop.
Based on the field observation and experiment in Samarinda, it was determined that the average attainable yield of tomato Ratna variety was 20 tons. ha ${ }^{-1}$, and the occurrence of PPN (Meloidogyne spp.) at population density of 2-3 juveniles. $\mathrm{g}^{-1}$ soil at harvest time reduced tomato productivity by about $57-77 \%$ (Table 1). The experiment was conducted at the field where tomato was previously planted, and with an unknown initial population density of Meloidogyne spp. but evenly distributed through soil tillage management. The population density development of plant-parasitic nematodes was prevented by applying chicken dung as a soil amendment treatment.

The potential productivity of tomato commercial varieties which are available in East Kalimantan was always above 40 tons. ha ${ }^{-1}$ (Purwati 2009). However, the annual average productivity of tomatoes reached in the East Kalimantan province was considered very low compared to the potential productivity, only ranging from $14.88 \%$ (2012) and up to $30.83 \%$ (2014) (Figure 1).

The highest attainable productivity of tomatoes occurred in Penajam Paser Utara district, being roughly 24.44 tons. ha $^{-1}$ (Table 2). But the productivity of tomatoes in other districts and cities was lower, therefore the annual average productivity of tomatoes in the province was still low. Based on the standard of the highest attainable productivity (24.44 ton. ha $\left.{ }^{-1}\right)$, the annual average productivity of tomatoes in the province ranged from $24.39 \%$ (2012) up to $50.45 \%$ (2014).

\section{The productivity of banana}

Banana is the number one fruit produced in East Kalimantan. Its production reached 72,114 tons in 2015 (BPS, 2015) or about $30 \%$ of total fruit production in the province which was composed of about 20 varieties of fruits. Banana farmers commonly cultivated their crop traditionally, and production inputs were not implemented to the crop. The risk of PPN infection at new banana plantations could come from the planting materials. Because banana farmers commonly used suckers as planting material, where small amounts of soil and root may have carried PPN in it. Afterward, the population of PPN increased and could cause significant yield loss and productivity reduction.

Based on the field survey and observation of PPN population density and banana yield in Kutai Kartanegara district, it was determined the relationships between PPN population density and productivity reduction on banana. The dominance of PPN genera at the observation area were Radopholus, Meloidogyne, and Pratylenchus. They all caused the productivity reduction on bananas, of Saba variety, in the upland area by about $41.67 \%$ and about $33.33 \%$ at the watershed area (Table 3 ). The productivity reduction on bananas was from the impact of PPN, at a population density of about 5891 and 4919 nematodes per $100 \mathrm{~g}$ of root, which generated the average root lesion at level of $55.9 \%$ and $39.8 \%$, respectively (Table 3 ). In the older banana plantations, without PPN control activities, the root lesion incident generally reached up to $90 \%$ - it was the precondition for toppling disease and productivity reduction by more than $75 \%$. 
Table 1. The relationships between plant-parasitic nematode (Meloidogyne spp.) population densities and productivity reduction of tomato in East Kalimantan Province, Indonesia

\begin{tabular}{cccc}
\hline $\begin{array}{c}\text { Chicken } \\
\text { dung } \\
\text { application } \\
\left.\text { ton.ha-1) }^{-1}\right)\end{array}$ & $\begin{array}{c}\text { Nematode } \\
\text { population } \\
\text { (juvenile per } \\
\text { 50g soil) }\end{array}$ & $\begin{array}{c}\text { Tomato } \\
\text { productivity } \\
\left.\text { (ton.ha- }^{-1}\right)\end{array}$ & $\begin{array}{c}\text { Productivity } \\
\text { reduction }(\%) \\
\text { based on } \\
\text { attainable tomato } \\
\text { yield }(\mathbf{2 0} \text { ton.ha-1) }\end{array}$ \\
\hline $0(\mathrm{Po})$ & 170 & 4.55 & 77.25 \\
$5\left(\mathrm{P}_{1}\right)$ & 140 & 5.34 & 73.30 \\
$10\left(\mathrm{P}_{2}\right)$ & 134 & 6.76 & 66.20 \\
$15\left(\mathrm{P}_{3}\right)$ & 122 & 7.91 & 60.45 \\
$20\left(\mathrm{P}_{4}\right)$ & 120 & 7.98 & 60.10 \\
$25\left(\mathrm{P}_{5}\right)$ & 110 & 8.59 & 57.05 \\
\hline
\end{tabular}

Table 2. Harvested area, productivity, and production of tomato at districts and cities of East Kalimantan province, Indonesia.

\begin{tabular}{llll}
\hline Districts/cities & $\begin{array}{l}\text { Harvested } \\
\text { area (ha) }\end{array}$ & $\begin{array}{l}\text { Productivity } \\
\text { (ton.ha }^{-1} \text { ) }\end{array}$ & $\begin{array}{l}\text { Production } \\
\text { (ton) }\end{array}$ \\
\hline Berau & 98 & 1.77 & 174 \\
Kutai Barat & 23 & 2.34 & 54 \\
Kutai Kartanegara & 467 & 12.47 & 5,823 \\
Kutai Timur & 68 & 1.88 & 128 \\
Mahakam Ulu & - & - & - \\
Paser & 22 & 5.30 & 117 \\
Penajam Paser Utara & 103 & 24.44 & 2,517 \\
Balikpapan & 191 & 17.66 & 3,374 \\
Bontang & 15 & 3.89 & 58 \\
Samarinda & 14 & 7.34 & 103 \\
\hline Source: BPS (2015) & & &
\end{tabular}

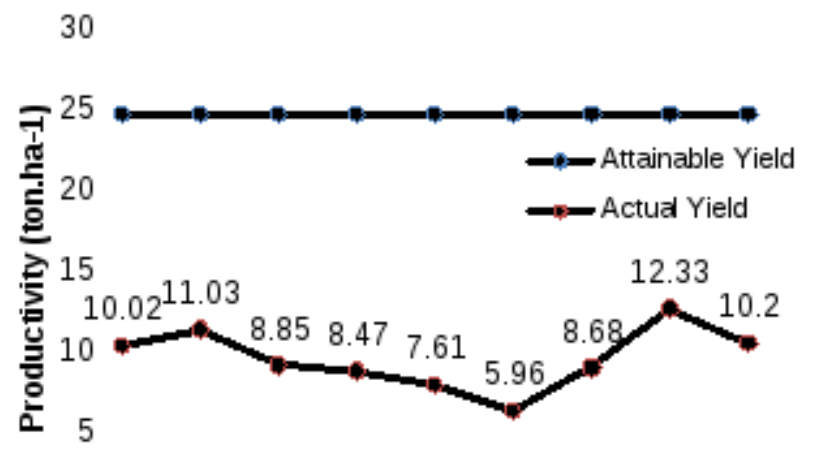

Figure 1. Tomato productivity trend in East Kalimantan (Sources: BPS, 2012 and 2015)

Table 3. The Relationships between plant-parasitic nematodes population density and productivity reduction on banana of Saba variety in Kutai Kartanegara district of East Kalimantan province, Indonesia

\begin{tabular}{ccccc}
\hline PPN & $\begin{array}{c}\text { Total of } \\
\text { Penera } \\
\text { PPN } \\
\text { population } \\
\text { density } \\
\text { (ind per } \\
\text { 100 g root) }\end{array}$ & $\begin{array}{c}\text { population } \\
\text { density } \\
\text { (ind 100 g } \\
\text { root) }\end{array}$ & $\begin{array}{c}\text { Average } \\
\text { root } \\
\text { lesion }\end{array}$ & $\begin{array}{c}\text { Productivity } \\
\text { reduction } \\
(\%)\end{array}$ \\
\hline
\end{tabular}

Watershed (periodically flooded area)

Radopholus 9106

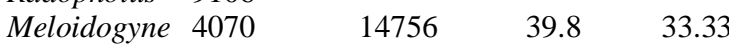

Pratylenchus 1580

Upland area

Radopholus 9967

Meloidogyne 4610

Pratylenchus 3095

$17672 \quad 55.9 \quad 41.67$

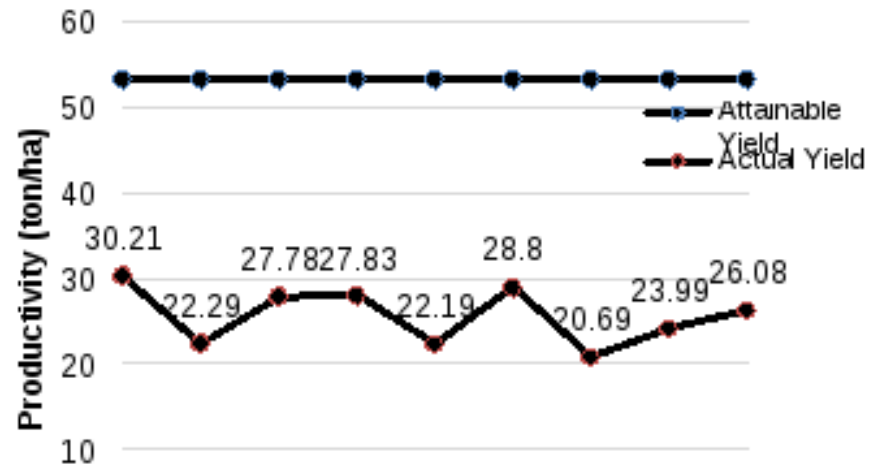

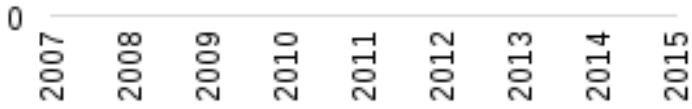

Figure 2. The banana productivity trend in East Kalimantan (Sources: BPS 2012 and 2015)

Table 4. Harvested area, productivity, and production of banana at districts and cities of East Kalimantan Province, Indonesia

\begin{tabular}{lccc}
\hline District/City & $\begin{array}{c}\text { Harvested } \\
\text { area (ha) }\end{array}$ & $\begin{array}{c}\text { Productivity } \\
\text { (ton/ha) }\end{array}$ & $\begin{array}{c}\text { Production } \\
\text { (ton) }\end{array}$ \\
\hline Paser & 500.77 & 18.48 & 9252 \\
Kutai Barat & 14.85 & 16.90 & 251 \\
Kutai & 717.27 & 22.12 & 15868 \\
Kartanegara & 694.12 & 30.37 & 21081 \\
Kutai Timur & 200.45 & 12.89 & 2584 \\
Berau & 264.94 & 11.34 & 3004 \\
Penajam Paser & - & - & - \\
Utara & 306.77 & 53.11 & 16292 \\
Mahakam Ulu & 188.28 & 20.10 & 3784 \\
Balikpapan & 5.28 & 12.12 & 64 \\
Samarinda & & & \\
Bontang & &
\end{tabular}


The average annual productivity of banana in the province (Figure 2) ranged from 20.69 ton.ha $^{-1}$ (2013) up to 30.21 ton.ha $^{-1}$ (2007) (BPS 2015), based on the highest attainable productivity (53.11 ton.ha ${ }^{-1}$ ) as the standard of determination (Table 4). It meant that the average annual productivity of banana in the province only reached $38.96 \%$ and up to $56.88 \%$. The banana productivity would be lower the well manage banana plantation, including integrated management of PPN, was considered.

\section{Discussion}

Plant-parasitic nematodes are a serious pest of agricultural ecosystems in East Kalimantan, but their existence is still neglected by farmers as well as Agricultural Government Officers. A special effort of extension and technologies dissemination for controlling this pest in provincial and districts level was still limited. However, research and field observations conducted by lecturers and students of Mulawarman University since 1990 proved that PPN was one of the important (silent) pests in East Kalimantan (Hambarwati 2004; Nur 2004; Nurmina 2006; Zulaichan 2007; Ngaini 2008; Sanjaya 2008; Sartono 2008; Septian 2011; Hidayat 2015, unpublished data). Population densities of plant-parasitic nematodes in agricultural ecosystems of East Kalimantan under intensive cultivation were always above the economic injury level. It was justified that plant-parasitic nematodes were causal pests that contributed to agricultural ecosystem productivity reduction.

East Kalimantan is situated in a tropical rain forest climatic zone and is considered a zone of flora and fauna diversity center, including plant-parasitic nematodes. Therefore, various genera of plant-parasitic and free leaving nematodes were observed in East Kalimantan, major plant-parasitic nematodes genera which frequently determined in agricultural ecosystem were: Meloidogyne, Radhopholus, Rotylenchulus, Helicotylenchus, Pratylenchus, and Tylenchorhynchus.

Meloidogyne was the most distributed nematode genus in East Kalimantan, this genus was the major pest on vegetable crops, and attacked both food crops and fruit crops. Genus of Radhopholus was the major pest of banana causing toppling disease in all banana development areas in the province. Genus of Rotylenchulus mostly attacked vegetables and food crops, especially those of the family Solanaceae and Leguminosae. Genera of Helicotylenchus and Pratylenchus have mostly attacked food crops of grasses family, and together with Radhopholus attacking banana. While Tylenchorhynchus seem to be adapted to perennial crops and cause serious damage to oil palm seedlings in Paser District of East Kalimantan (Suyadi 2010, unpublished data).

\section{The role of plant-parasitic nematodes on the tomato productivity reduction}

In relation to the role of plant-parasitic nematodes as the causal agent of tomato productivity reduction, it could be elaborated by the fact that the higher tomato yield was reached at the area of tomato production centers, such as Balikpapan city, Penajam Paser Utara and Kutai
Kartanegara districts (Table 2). It was due to the impact of the organic soil amendment which is commonly applied by farmers at the area of tomato production centers. Organic soil amendments, especially animal dung, are beneficial for soil fertility improvement. It also played a role as nutrient source for natural enemies of plant-parasitic nematodes. Therefore, those natural enemies suppressed the population of plant-parasitic nematodes and can be more effective than synthetic nematicides (Aalders et al. 2009).

Tomato is one of the important vegetable crops in East Kalimantan, and tomato farmers always manage their crops intensively, including pest control activities. Essentially, the major pest of tomato was successfully solved, except for PPN - because the existence of PPN is undistinguished due to their microscopic size and wrapped in the soil particles or plant roots. However, most farmers in the province were still applying inorganic fertilizers and pesticides as the component of production inputs for their tomato crop. Consequently, the population of PPN was always above the economic injury level and caused a significant yield loss.

The impact of inorganic fertilizers and pesticides application will reduce the diversity of soil micro-flora and fauna, including those natural enemies of PPN. Whereas the surviving PPN of tomatoes will be free from their enemies, and their population will increase rapidly to reach the economic injury level. Therefore, the productivity reduction caused by the PPN cannot be rejected, and the average annual productivity of tomatoes in the province is considered low, only ranging from $24.39 \%$ (2012) up to $50.45 \%$ (2014) compared to the attainable yield (Figure 1 and Table 2). This means that the productivity reduction of tomatoes caused by PPN in East Kalimantan occurred at about $49.55 \%$ up to $75.61 \%$. Furthermore, the productivity reduction will be higher, if the potential yield (40 ton.ha. ${ }^{-1}$ ) is considered as the comparison standard, so therefore productivity reduction of tomato caused by PPN in East Kalimantan will be about $69.17 \%$ up to $85.12 \%$.

\section{The role of plant-parasitic nematodes on the banana productivity reduction}

The opposite crop management of tomato was implemented on bananas, as most banana farmers managed their crop traditionally and they never provide any production input to their crop. They just plant the banana suckers and sometimes implement weed control, and then leave them up to harvest time. Fortunately, bananas in East Kalimantan was relatively not faced with a serious pest attack, except for the outbreak of bacterial wilt disease in early 2000 (Suyadi 2007). However, the impact of bacterial wilt disease could be easily differentiated from the PPN in the banana productivity reduction. Because eradication treatment was implemented to bananas infected by bacterial wilt.

Plant-parasitic nematodes distributed simultaneously with the distribution of planting material, because together with the suckers were carried a small amount of soil and/or banana roots that contained PPN in it. Then, those PPN will reproduce rapidly on suitable hosts. As we know that the life cycle of plant-parasitic nematodes is just about one 
month under suitable environmental conditions. It means, the population density of plant-parasitic nematodes in a year will almost reach the economic injury level, if natural enemies are not functioning effectively to reduce the population of PPN. Consequently, banana yield will drastically reduce at third or fourth harvest and afterward, but farmers often don't pay any attention to control the PPN. They just expect that yield reduction was due to nutrient shortage and soil fertility reduction.

In relation to the role of PPN in the reduction of banana productivity, field observations determined that PPN was the causal agent of drastic yield reduction on saba cultivar banana (the most common banana cultivar planted by farmer in East Kalimantan). At first harvest of the newly planted banana, farmers will harvest bunches of bananas with $>10$ combs which are composed of 18 fingers each comb on average, but from the fourth harvest farmers will only get a banana bunch with five or fewer combs and smaller fingers, if the proper management of plant-parasitic nematodes was not implemented (Swandono et al. 2009; Suyadi 2013). Based on the explanations stated above, and determination of the average annual productivity based on the attainable yield (Figure 2 and Table 4) experiencing yield loss on banana of about $61 \%$ was common in the province, because quantitatively the number of combs was reduced and qualitatively the size of fingers become smaller. The highest productivity reduction of bananas in the province could reach $78.65 \%$ (Table 4 ).

Just like in the tomato management case, farmers controlling PPN on banana was only indirect, as it was the impact of organic manure application as soil amendment. Then, the organic manure will supply a nutrient to the crop as well as provide a "food" for natural enemies of PPN. That could easily be distinguishable on the banana planted around the farmers housing, where those banana plants always received organic material from the household waste.

\section{ACKNOWLEDGEMENTS}

We are very grateful to the students who were involved in the field research, gathering primary data. Also, we are thankful to the Statistic Center Bureau of East Kalimantan Province for providing the secondary data.

\section{REFERENCES}

Aalders LT, Minchin R, Hill RA, Braithwaite M, Bell NL, Stewart A. 2009. Development of a tomato/root knot nematode bioassay to screen beneficial microbes. N Z Plant Protect 62: 28-33.
Bartholomew ES, Brathwaite RAI, Isaac WP. 2014. Control of rootburrowing nematode (Radopholus similis) in banana using extracts of Azadirachta indica and Allium sativum. J Organic Syst 9 (2): 49-55.

BPS. 2012. Statistic of Vegetables and Fruits East Kalimantan Province, Year 2012. Badan Pusat Statistik Provinsi Kalimantan Timur.

BPS. 2015. Statistic of Vegetables and Fruits East Kalimantan Province, Year 2015. Badan Pusat Statistik Provinsi Kalimantan Timur.

Brooks FE. 2008. Burrowing Nematode. The Plant Health Instructor. DOI: 10.1094/PHI-I-2008-1020-01. www.apsnet.org.

Chitamba J, Manjeru P, Chinheya CC, Mudada N, Handiseni M. 2013. Plant-parasitic nematodes associated with banana (Musa spp.) in Rusitu Valley, Zimbabwe. Nematropica 43:113-118.

Gharabadiyan F, Jamali S, Komeili HR. 2013. Determining of root-knot nematode (Meloidogyne javanica) damage function for tomato cultivars. J Agric Sci 58 (2): 147-157.

Hölscher D, Dhakshinamoorthyc S, Alexandrovd T, Beckerh M, Bretschneideri T, Buerkertb A, Creceliusj AC, De Waelec D, Elsenl A, Heckelm DG, Heklaun H, Hertwecki C, Kaio M, Knopj K, Krafftp C, Maddulao RK, Matthäusp C, Poppp J, Schneidera B, Schubertj US, Sikoras RA, Svatošo A, Swennenc RL. 2014. Phenalenone-type phytoalexins mediate resistance of banana plants (Musa spp.) to the burrowing nematode Radopholus similis. Proc Natl Acad Sci USA 111 (1): 105-110.

Jones JT, Haegeman A, Danchin EGJ, Gaur HS, Helder J, Jones MGK, Kikuchi T, Manzanilla-López R, Palomares-Rius JE, Wesemael WML, Perry RN. 2013. Top 10 plant-parasitic nematodes in molecular plant pathology. Mol Plant Pathol 14 (9): 946-961.

Kamira M, Hauser S, Van Asten P, Coyne D, Talwana HL. 2013. Plantparasitic nematodes associated with banana and plantain in eastern and western Democratic Republic of Congo. Nematropica 43 (2): 216-225.

Purwati, E. 2009. Daya Hasil Tomat Hibrida $\left(\mathrm{F}_{1}\right)$ di Dataran Medium. J Hort 19(2): 125-130.

Rani CI, Muthuvel I, Veeraragavathatham D. 2009. Evaluation of 14 genotypes for yield and root knot nematodes resistance parameters. Pest Tech 3 (1): 76-80.

Risède JM, Chabrier C, Dorel M, Dambas T, Achard R, Quénéhervé P. 2010. Integrated management of banana nematodes: Lessons from a case study in the French West Indies. From Science to Field, Banana Case Study - Guide Number 4, CIRAD, France.

Seid A, Fininsa C, Mekete T, Decraemer W, Wesemael WML. 2015. Tomato (Solanum lycopersicum) and root-knot nematodes (Meloidogyne spp.) - a century-old battle. Nematology 17 (9): 995100

Singh R, Kumar U. 2015. Assessment of nematode distribution and yield losses in vegetable crops of Western Uttar Pradesh in India. Intl J Sci Res 4 (5): 2812-2816.

Srinivasan R, Kulothungan S, Sundararaju P, Govindasamy C. 2011. Biodiversity of plant-parasitic nematodes associated with banana in Thanjavur District of Tamil Nadu. Intl J Plant Anim Environ Sci 1 (2): 63-69.

Suyadi. 2007. Study of Disease Incidences of Bacterial Wilt on Banana in East Kalimantan. Tanitrop 22 (1): 15-18. [Indonesian]

Suyadi. 2013. The damage status and dispersal of burrowing nematode (Radopholus similis) on banana in East Kalimanatan. In Nasir et al. (eds) Fitopatologi untuk Mendukung Kemandirian Pangan dan Ekonomi Berbasis Iptek Ramah Lingkungan. Proceeding Seminar dan Kongres Nasional Ke XXII Perhimpunan Fitopatologi Indonesia. Pangeran Beach Hotel, Padang, 7-10 Oktober 2013. [Indonesian]

Swandono, Suyadi, Jannah, N. 2009. Distribution of plant parasite nematodes at banana root of saba variety in upland area. Jurnal Budidaya Pertanian: 15 (3): 150-155. [Indonesian] 